\title{
Efektivitas dan Kontribusi Pajak Perhotelan terhadap Pendapatan Asli Daerah Kabupaten Indragiri Hulu Tahun 2013-2019
}

\author{
Aris Triyono $^{1 *}$, Albetris ${ }^{2}$, Sumantri $^{3}$, Etty Siswati ${ }^{4}$ \\ ${ }^{1}$ STIE Indragiri Rengat \\ ${ }^{2}$ Universitas Batanghari Jambi \\ ${ }^{3,4}$ STIE Graha Karya Muara Bulian, Jambi \\ *Correspondence email: arist@stieindragiri.ac.id, albetris90@gmail.com, Sumantri.baharun123@gmail.com, \\ ettysiswati793@gmail.com
}

\begin{abstract}
Abstrak. Pelaksanaan Penelitian dilakukan di Badan Pendapatan Daerah Kabupaten Indragiri Hulu. Tujuan penelitian ini adalah untuk menganalisis dan mengetahui seberapa besar pengaruh Efektivitas dan kontribusi pajak Perhotelan Terhadap Pendapatan Asli Daerah Kabupaten Indragiri Hulu baik secara simultan maupun secara parsial dengan periode penelitian adalah 5 tahun dari Tahun 2013 hingga tahun 2019. Jenis penelitian ini adalah penelitian kuantitatif dengan menggunakan data sekunder. Metode Penelelitian yang digunakan adalah Metode kuantitatif dengan Persamaan regresi linear berganda, adapun Persamaannya adalah $\mathbf{Y}$ = 45712635725,406 - 19524572,193 X $\mathbf{X}_{\mathbf{1}}+\mathbf{2 5 7 6 5 5 5 , 8 1 7} \mathbf{X}_{2}$. Dari Hasil Pengolahan data SPSS diketahui secara simultan diketahui jika Efektivitas dan kontribusi penerimaan pajak Perhotelan berpengaruh signifikan terhadap pendapatan asli daerah. Dari hasil SPSS, diketahui secara parsial tidak terdapat pengaruh yang signifikan antara Efektivitas terhadap pendapatan asli daerah dan secara parsial terdapat pengaruh yang signifikan antara Kontribusi penerimaan pajak hotel secara parsial terhadap pendapatan asli daerah.
\end{abstract}

Kata Kunci: Efektivitas; Kontribusi Penerimaan Pajak Hotel; Pendapatan Asli Daerah

\begin{abstract}
The research was conducted at the Regional Revenue Agency of Indragiri Hulu Regency. The purpose of this study is to analyze and find out how much effect the Effectiveness and contribution of Hospitality tax to the Original Revenue of Indragiri Hulu Regency both simultaneously and partially with the research period is 5 years from 2013 to 2019. This type of research is quantitative research using secondary data. The Research Method used is quantitative method with multiple linear regression equations, while the Equation is $Y=45712635725,406-19524572,193$ X1 $+25765555,817$ X2. From the results of data processing SPSS is known simultaneously known if the effectiveness and contribution of hospitality tax receipts have a significant effect on the original revenue of the region. From the SPSS results, it is known that there is partially no significant influence between effectiveness to the original revenue of the region and partially there is a significant influence between the contribution of hotel tax receipts partially to the original revenue of the region.
\end{abstract}

Keywords: Effectiveness; Hotel Tax Receipt Contribution; Regional Native Income

\section{PENDAHULUAN}

Hasil Dari pajak daerah, retribusi Daerah, pengelolaan kekayaan daerah Terpisah, dan pendapatan asli daerah lain - lain yang sah merupakan Pendapatan Asli Daerah (PAD), Tujuan dari PAD adalah kepada daerah dapat secara leluasa menggali pendanaan sekaligus mewujudkan asas desentralisasi dan otonomi daerah (PRESIDENRI, 2004). Berikut peneliti sajikan data Target dan Realisasi Pajak Hotel Juga PAD Kabupaten Indragiri Hulu Tahun 2013-2019:

Tabel 1. Target dan Realisasi Pajak Hotel, Pendapatan Asli Daerah (PAD) Kabupaten Indragiri Hulu Periode 2013-2019

\begin{tabular}{ccccc}
\hline Tahun & $\begin{array}{c}\text { Target Pajak } \\
\text { Perhotelan }\end{array}$ & $\begin{array}{c}\text { Realisasi Pajak } \\
\text { Perhotelan }\end{array}$ & Target PAD & Realisasi PAD \\
\hline 2013 & $175,000,000$ & $355,839,625$ & $52,683,145,618$ & $72,360,357,167$ \\
2014 & $221,665,318$ & $476,095,100$ & $62,409,888,691$ & $111,827,898,830$ \\
2015 & $320,255,662$ & $490,193,020$ & $103,357,697,903$ & $125,148,593,066$ \\
2016 & $476,095,000$ & $430,389,796$ & $89,808,068,044$ & $98,845,361,438$ \\
2017 & $451,909,286$ & $339,281,490$ & $164,429,903,083$ & $159,679,708,583$ \\
2018 & $465,466,564$ & $408,936,605$ & $159,679,708,583$ & $111,900,731,074$ \\
2019 & $423,872,630$ & $437,437,422$ & $115,670,377,495$ & $125,914,178,143$ \\
\hline
\end{tabular}

Sumber: Badan Pendapatan Daerah Indragiri Hulu, Tahun 2020
Dari tabel yang penulis sampaikan di atas dapat diketahui Jika efektivitas pajak hotel dan PAD Indragiri hulu dari tahun 2013-2019 mengalami fluktuasi artinya ada kenaikan dan penurunan. Dengan demikian, efektivitas pajak perhotelan dan pendapatan asli daerah pada Kabupaten Indragiri Hulu belum menunjukkan hasil yang maksimal. Faktor yang mempengaruhi PAD (Memah, 2013) Adalah Efektivitas Penggunaan Dana, Efektivitas penghubung antara hasil dengan tujuan yang harus terealisasi. Kapan bisa dikategorikan efektif yaitu jika tujuan atau sasaran akhir kebijakan (spending wisely) telah di capai dan melewati proses kegiatan.

Efektif lebih menekankan pada tepat sasaran. Efektifitas bukan hanya tentang seberapa besar biaya yang sudah di gunakan agar tujuan tercapai, Biaya bisa saja melampaui biaya yang telah sediakan, bisa saja satu, dua ataupun tiga kali banyak daripada yang telah Sediakan (Ariyanti et al., 2020). Hasil penelitian yang dilakukan oleh (Agus et al., 2020; Ardiansyah, 2015; ASMAWATI \& HESTI, 2021; Benita et al., 2019; Bustomi, 2021; Dwihandoko, 2020; Hafandi \& Romandhon, 2020; Irfani et al., 2019; Jamli \& Rahayu, 
Aris Triyono, Albetris, Sumantri dan Etty Siswati, Efektivitas dan Kontribusi Pajak Perhotelan terhadap Pendapatan Asli Daerah Kabupaten Indragiri Hulu Tahun 2013-2019

1997; Jaya \& Nopiana, 2019; Karini \& Agustiani, 2018; Koromath, 2019; Kurniawan et al., 2021; Maulida et al., 2019; Nathania, 2019; Pramesthi \& Adnan, 2015; Purnamawati, 2014; Puspitasari \& Rohman, 2014; Renindita \& Novianty, 2020; Rohma, 2017; Samosir, 2020; Soleh, 2020; Suhono \& Sulastri, 2017; Sunanto, 2017; Triwinarso, 2018; Wahyuni \& Arief, 2020; Yasa, 2020) menegaskan terdapat Pengaruh Efektivitas Terhadap Pendapatan Asli Daerah (PAD).

Selanjutnya faktor yang mempengaruhi Pendapatan Asli Daerah yaitu kontribusi pajak, Kontribusi pajak ini adalah untuk melihat sampai dimanakah pajak daerah memberikan sumbangan dalam penerimaan PAD (Barus \& Kariono, 2013; Hahumury, 2018; Hasanah \& Anitasari, 2019; Hidayat \& Pahlevi, 2016; Nababan \& Putra, 2018; Ruslan, 2016; Saputra \& Nurfitriana, 2020; Susanto \& Anggraini, 2019; Susianti et al., 2016; Zainita et al., 2016). Dalam mengetahui kontribusi tersebut bisa dilakukan dengan membandingkan antara penerimaan pajak daerah (khususnya pajak hotel dan pajak restoran) periode tertentu dengan penerimaan PAD periode tertentu pula. Jika Semakin besar hasil kotribusi Pajak tersebut maka pendapatan PADpun akan berkorelasi positif, begitu pula sebaliknya jika hasil semakin kecil bisa dikatakan peranan pajak daerah terhadap PAD akan semakin kecil.

(Ali et al., 2020; Anggani, 2016; Biringkanae \& Tammu, 2021; Handryani et al., 2014; Lianawati, 2015; Raysa \& Purba, 2020; Sahrudin, 2017; Zainita et al., 2016)menyatakan Terdapat Pengaruh Efektivitas dan Kontribusi Penerimaan Pajak Hotel Terhadap Peningkatan Pendapatan Asli Daerah (PAD). Penelitian ini juga di dukung oleh (Hasbullah et al., 2021; Hilman \& Kartika, 2020; Isrok, 2009; Jainuri, 2019; Ningsih, 2017; Pitriyani, 2020; Pratiwi et al., 2021; ROHMAN, 2016; Said \& Ode, n.d.). Dari fenomena dam pencapaian realisasi PAD di Kabupaten inderagiri Hulu, kajian teoritis dan penelitian terdahulu yang belum ada kata mufakat maka peneliti tertarik untuk melakukan penelitian lebih lanjut.

\section{METODE}

Lokasi Penelitian dilakukan di Kabupaten Indragiri Hulu dengan periode pengamatan 2013 - 2019. Jenis data merupakan data sekunder dan Sumber Data berasal dari dinas yang terkait dengan penelitian. Jenis penelitian ini menggunakan Mix Method (Blunch, 2012).

\section{Analisis Data}

Uji Asumsi Klasik (Ho, 2006):

1. Uji Normalitas;

2. Uji Multikolinearitas;

3. Uji Autokorelasi;

4. Uji Heteroskedastisitas.

Regresi Linear Berganda;
Dengan rumus persamaan regresi (Blunch, 2012):

$\mathbf{Y}=\mathbf{a}+\mathbf{b}_{1} \mathbf{X}_{1}+\mathbf{b}_{2} \mathbf{X}_{2}+\mathbf{e}$

Dimana, untuk mendapatkan nilai koefisien:

$\Sigma Y=a n+b 1 \Sigma x 1+b 2 \Sigma x 2$

$\Sigma x 1=a \Sigma x 1+b 1 \Sigma x 12+b 2 \Sigma x 1 \Sigma x 2$

$\Sigma x 2=a \Sigma x 2+b 1 \Sigma x 1 x 2+b 2 \Sigma x 2$

\section{Uji Hipotesis}

Uji Simultan (Uji F) (Blunch, 2012); Uji F digunakan untuk mengetahui pengaruh variabel bebas (independen) terhadap variabel terikat (dependen) secara Simultan.

Uji Parsial (Uji t) (Blunch, 2012); Uji t digunakan untuk mengetahui pengaruh variabel bebas (independen) terhadap variabel terikat (dependen) secara Parsial.

\section{HASIL DAN PEMBAHASAN \\ Uji Asumsi Klasik \\ Uji Normalitas}

Tabel 2. Hasil Uji Normalitas

One-Sample Kolmogorov-Smirnov Test

\begin{tabular}{llr}
\hline & & Unstandardized Residual \\
\hline $\mathrm{N}$ & & 7 \\
Normal Parameterga, & Mean & -.0000054 \\
& Std. Deviation & 12720972436.45701200 \\
& Absolute & .181 \\
Most Extreme Differences & Positive & .152 \\
& Negative & -181 \\
Kolmogorov-Smirnov Z & & -478 \\
Asymp. Sig. (2-tailed) & .977 \\
\hline a. Test distribution is Normal. \\
b. Calculated from data. \\
Sumber: Hasil Penelitian Output SPSS Versi 20
\end{tabular}

Hasil uji normalitas menunjukkan bahwa semua variabel penelitian mempunyai nilai lebih besar dari 0,05 pada $(0,478>0,05)$, sehingga dapat disimpulkan bahwa data penelitian berdistribusi normal.

\section{Uji Multikolinieritas}

Tabel 3. Hasil Uji Multikolinieritas

\begin{tabular}{|c|c|c|c|c|c|c|c|}
\hline \multirow{3}{*}{$\overline{\text { Model }}$} & \multicolumn{5}{|c|}{ Coefficients $^{\mathrm{a}}$} & \multirow{2}{*}{\multicolumn{2}{|c|}{ Collinearity Statistics }} \\
\hline & \multicolumn{2}{|c|}{ Unstandardized Coefficients } & \multirow{2}{*}{$\begin{array}{c}\text { Standardized } \\
\text { Coefficients } \\
\text { Beta }\end{array}$} & \multirow[t]{2}{*}{$\mathrm{T}$} & \multirow[t]{2}{*}{ Sig. } & & \\
\hline & B & Std. Error & & & & Tolerance & VIF \\
\hline (Constant) & 45712635725.406 & 38961379004.041 & & 1.173 & .306 & & \\
\hline $\mathrm{X} 1$ & -19524572.193 & 136718956.111 & -.042 & -.143 & .893 & .645 & 1.550 \\
\hline $\mathrm{X} 2$ & 2576555.817 & 890096.794 & .855 & 2.895 & .044 & .645 & 1.550 \\
\hline
\end{tabular}

Sumber: Hasil Penelitian Output SPSS Versi 20

Berdasarkan tabel diatas terlihat bahwa variabel pengaruh efektivitas dan kontribusi penerimaan pajak perhotelan memiliki nilai tolerance diatas 0,10 dan VIF lebih kecil dari 10. Dengan nilai tolerance sebesar 0,645 dan VIF sebesar 1,550. Berarti tidak terjadi multikoliniaritas, sehingga data dapat digunakan dalam penelitian ini.

\section{Uji Heteroskedastisitas}

Hasil pengujian heteroskedastisitas dapat dilihat pada gambar di bawah ini: 


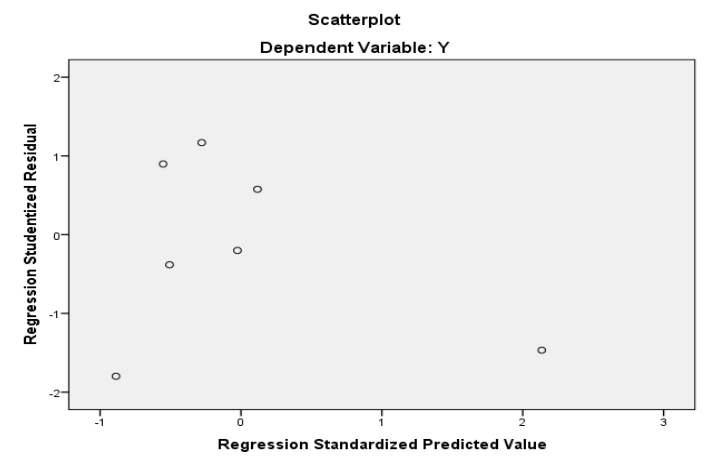

Gambar 1. Uji Heteroskedastisitas Menggunakan Scatterplot

Dari gambar scatterplot diatas dapat dilihat bahwa data tersebar dan tidak membentuk suatu pola. Hal ini menunjukkan bahwa tidak terjadi heterokedaktisitas, sehingga model ini dikatan layak digunakan untuk memprediksi efektivitasn dan kontribusi penerimaan pajak perhotelan terhadap PAD.

\section{Uji Autokorelasi}

Tabel 4. Hasil Uji Autokorelasi Model Summary ${ }^{b}$

\begin{tabular}{lcrrrr}
\hline Model & R & R Square & Adjusted R Square & Std. Error of the Estimate & Durbin-Watson \\
\hline 1 & $.880^{\mathrm{a}}$ & .775 & .663 & 15579945750.664 & 1.655 \\
\hline a. Predictors: (Constant), X2, X1 & & & &
\end{tabular}

b. Dependent Variable: Y

Sumber: Hasil Penelitian Output SPSS Versi 21.00, Data

Diolah (2020)

Dari data diatas diketahui jika nilai uji durbin watson dari nilai sebesar $1,655>0,05$. maka dapat disimpulkan tidak terjadi autokorelasi.

\section{Analisis Regresi Linear Berganda}

Tabel 5. Hasil Analisis Regresi Linear Berganda

\begin{tabular}{|c|c|c|c|c|c|c|c|}
\hline \multirow{3}{*}{ Model } & \multicolumn{4}{|c|}{ Coefficients $^{\mathrm{a}}$} & \multirow{3}{*}{ Sig. } & \multirow{2}{*}{\multicolumn{2}{|c|}{$\begin{array}{l}\text { Collinearity } \\
\text { Statistics }\end{array}$}} \\
\hline & Unstandardize & Coefficients & $\begin{array}{l}\text { Standardized } \\
\text { Coefficients }\end{array}$ & $\mathrm{t}$ & & & \\
\hline & B & Std. Error & Beta & & & Tolerance & VIF \\
\hline (Constant) & 45712635725.406 & 38961379004.041 & & 1.173 & .306 & & \\
\hline $1 \mathrm{X} 1$ & -19524572.193 & 136718956.111 & -.042 & -.143 & .893 & .645 & 1.550 \\
\hline $\mathrm{X} 2$ & 2576555.817 & 890096.794 & .855 & 2.895 & .044 & .645 & 1.550 \\
\hline
\end{tabular}

Sumber: Hasil Penelitian Output SPSS Versi 20.00

Berdasarkan tabel di atas, dapat disusun dalam suatu model antara pengaruh efektivitas $\left(\mathrm{X}_{1}\right)$ dan kontribusi penerimaan pajak hotel $\left(\mathrm{X}_{2}\right)$ terhadap pendapatan asli daerah (Y) yaitu sebagai berikut:

\section{$Y=45712635725,406-19524572,193 X_{1}+2576555,817 X_{2}$}

Dengan persamaan regresi di atas dapat dijelaskan sebagai berikut:

$\mathrm{a}=45712635725,406$. Hal ini menunjukkan bahwa jika pengaruh efektivitas (variabel $\mathrm{X}_{1}$ ) dan kontribusi penerimaan pajak hotel (variabel $\mathrm{X}_{2}$ ) memiliki nilai sama dengan nol maka nilai pendapatan asli daerah (variabel Y) sebesar 45712635725,406 . $\mathrm{b}_{1} \quad=$ Nilai koefisien $\mathrm{X}_{1}:-19524572,193$ berarti bahwa apabila pengaruh efektivitas $\left(\mathrm{X}_{1}\right)$ naik sebesar satu satuan, sementara variabel kontribusi penerimaan pajak hotel $\left(\mathrm{X}_{2}\right)$ tetap maka pendapatan asli daerah akan mengalami peningkatan sebesar -19524572,193 dan sebaliknya apabila pengaruh efektivitas $\left(\mathrm{X}_{1}\right)$ terjadi penurunan sebesar satu satuan, sementara variabel kontribusi penerimaan pajak hotel $\left(\mathrm{X}_{2}\right)$ tetap maka pendapatan asli daerah (Y) akan mengalami penurunan sebesar -19524572,193.

$\mathrm{b}_{2}=$ Nilai koefisien $\mathrm{X}_{2}=2576555,817$ hal ini menerangkan apabila kontribusi penerimaan pajak hotel $\left(\mathrm{X}_{2}\right)$ naik sebesar satu satuan, sementara variabel pengaruh efektivitas $\left(X_{1}\right)$ tetap maka pendapatan asli daerah akan mengalami peningkatan sebesar 2576555,817 dan apabila kontribusi penerimaan pajak hotel $\left(\mathrm{X}_{2}\right)$ turun sebesar satu satuan, sementara variabel pengaruh efektivitas $\left(\mathrm{X}_{1}\right)$ tetap maka pendapatan asli daerah (Y) akan mengalami penuruan sebesar 2576555,817 .

\section{Analisis Koefisien Korelasi Linear Berganda (R)}

Tabel 6. Koefisien Korelasi Linear Berganda (R) Model Summary ${ }^{\text {b }}$

\begin{tabular}{lrrrrr}
\hline Model & $R$ & $\begin{array}{c}\text { R } \\
\text { Square }\end{array}$ & $\begin{array}{c}\text { Adjusted } \\
\text { R Square }\end{array}$ & $\begin{array}{c}\text { Std. Error of the } \\
\text { Estimate }\end{array}$ & $\begin{array}{c}\text { Durbin- } \\
\text { Watson }\end{array}$ \\
\hline 1 & $.880^{\mathrm{a}}$ & .775 & .663 & 15579945750.664 & 1.655 \\
\hline a. Predictors: (Constant), X2, X1 & & \\
b. Dependent Variable: Y \\
Sumber: Hasil Penelitian Output SPSS Versi 20.00
\end{tabular}

Dari tabel diatas di ketahui nilai koefisien korelasi adalah 0,880 . Sehingga dapat dinyatakan terdapat hubungan antara $X_{1}$ (pengaruh efektivitas) dan $X_{2}$ (kontribusi penerimaan pajak hotel) terhadap $\mathrm{Y}$ (pendapatan asli daerah) yang dikategorikan kuat. Adapun pedoman untuk memberikan interprestasi koefisien korelasi menurut (Thakkar, 2013) adalah sebagai berikut:

Tabel 7. Interpretasi Koefisien Korelasi

\begin{tabular}{|c|c|}
\hline Interval Koefisien & Tingkat Hubungan \\
\hline $0,00-0,199$ & Sangat Rendah \\
\hline $0,20-0,399$ & Rendah \\
\hline $0,40-0,599$ & Sedang \\
\hline $\mathbf{0 , 6 0 - 0 , 7 9 9}$ & Kuat \\
\hline $0,80-1,000$ & Sangat Kuat \\
\hline
\end{tabular}

Sumber: Sugiyono, 2010: 243

Analisis Koefisien Determinasi $\left(\boldsymbol{R}^{2}\right)$ 
Aris Triyono, Albetris, Sumantri dan Etty Siswati, Efektivitas dan Kontribusi Pajak Perhotelan terhadap Pendapatan Asli Daerah Kabupaten Indragiri Hulu Tahun 2013-2019

Tabel 8. Analisis Koefisien Determinasi Model Summary ${ }^{\mathrm{b}}$

\begin{tabular}{lccccc}
\hline Model & R & $\begin{array}{c}\text { R } \\
\text { Square }\end{array}$ & $\begin{array}{c}\text { Adjusted } \\
\text { R Square }\end{array}$ & $\begin{array}{c}\text { Std. Error of the } \\
\text { Estimate }\end{array}$ & $\begin{array}{c}\text { Durbin- } \\
\text { Watson }\end{array}$ \\
\hline 1 & $.880^{\mathrm{a}}$ & .775 & .663 & 15579945750.664 & 1.655 \\
\hline a. Predictors: (Constant), X2, X1 & & \\
b. Dependent Variable: Y \\
Sumber: Hasil Penelitian Output SPSS Versi 20
\end{tabular}

Dari data diatas diketahui bahwa koefisen determinasi (Rsquare) yang diperoleh sebesar 0,775= $77,5 \%$. Hal ini menunjukkan jika efektivitas (variabel $\mathrm{X}_{1}$ ) dan kontribusi penerimaan pajak hotel (variabel $\mathrm{X}_{2}$ ) memiliki pengaruh terhadap pendapatan asli daerah (variabel Y) sebesar 77,5\% dan 22,5\% lainnya dipengaruhi oleh faktor-faktor lain yang tidak termasuk dalam variabel penelitian ini.

\section{Uji Hipotesis}

\section{Uji Simultan (Uji F)}

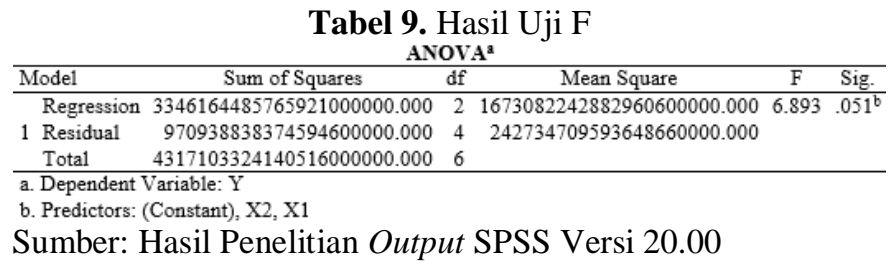

Dari data di atas dapat diketahui bahwa nilai $\mathrm{F}_{\text {hitung }}$ adalah 6,893 dengan tingkat signifikan 0,000. Sedangkan $\mathrm{F}_{\text {tabel }}$ pada taraf kepercayaan $95 \%(0,05)$ adalah 6,94. Maka diperoleh $F_{\text {hitung }}<\mathrm{F}_{\text {tabel }}$ yaitu 6,893 $<$ 6,94 . Hal ini berarti Ho diterima dan Ha ditolak, artinya secara simultan pengaruh efektivitas dan kontribusi penerimaan pajak hotel tidak berpengaruh signifikan terhadap pendapatan asli daerah.

\section{Uji Parsial (Uji t)}

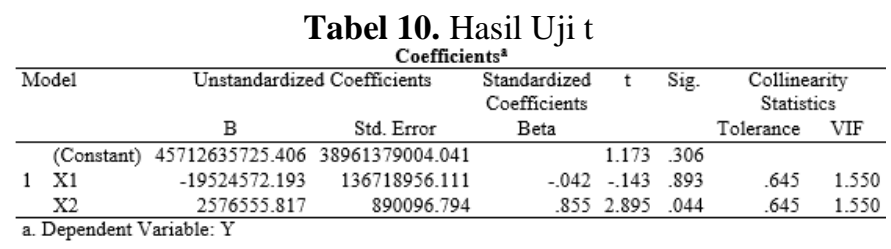

Sumber: Hasil Penelitian Output SPSS Versi 20

1. Pada tabel di atas nilai $t_{\text {hitung }} \mathrm{X}_{1}<\mathrm{t}_{\text {tabel }}=-0,143<-$ 2,57058 sehingga Ha diterima dan Ho ditolak, yang berarti variabel independen $\left(\mathrm{X}_{1}\right)$ efektivitas secara parsial tidak berpengaruh signifikan terhadap variabel pendapatan asli daerah (Y).

2. Selanjutnya nilai $t_{\text {hitung }} X_{2}>t_{\text {tabel }}=2,895>2,57058$ sehingga Ho ditolak dan Ha diterima, yang berarti variabel independen $\left(\mathrm{X}_{2}\right)$ kontribusi penerimaan pajak hotel secara parsial berpengaruh signifikan terhadap variabel pendapatan asli daerah $(\mathrm{Y})$.

\section{SIMPULAN}

1. Hasil perhitungan statistik uji $\mathrm{F}$ diperoleh $\mathrm{F}$ hitung < $\mathrm{F}_{\text {tabel}}$, berarti Ho diterima dan Ha ditolak, artinya secara simultan pengaruh efektivitas dan kontribusi penerimaan pajak hotel tidak berpengaruh signifikan terhadap pendapatan asli daerah.

2. Hasil perhitungan statistik uji-t diperoleh nilai $t_{\text {hitung }}$ $\mathrm{X}_{1}<\mathrm{t}_{\text {tabel }}$ sehingga Ho ditolak dan Ha diterima, yang berarti variabel independen $\left(\mathrm{X}_{1}\right)$ efektivitas secara parsial tidak berpengaruh signifikan terhadap variabel pendapatan asli daerah (Y).

3. Hasil perhitungan statistik uji-t diperoleh nilai thitung $X_{2}>t_{\text {tabel }}$ sehingga Ha diterima dan Ho ditolak, yang berarti variabel independen $\left(\mathrm{X}_{2}\right)$ kontribusi penerimaan pajak hotel secara parsial berpengaruh signifikan terhadap variabel pendapatan asli daerah (Y).

\section{DAFTAR PUSTAKA}

Agus, R. M., Mahfudnurnajamuddin, M., \& ... (2020). Kontribusi Pajak Bumi dan Bangunan Terhadap Pendapatan Asli Daerah. ... Students Journal. https://mail.jurnal.fe.umi.ac.id/index.php/CESJ/art icle/view/539

Ali, U. R., Manik, T., \& Husna, A. (2020). PENGARUH JUMLAH KUNJUNGAN WISATAWAN TERHADAP PENDAPATAN ASLI DAERAH MELALUI PAJAK HOTEL SEBAGAI VARIABEL INTERVENING. ... Online Journal (SOJ) UMRAH-Ekonomi. https://soj.umrah.ac.id/index.php/SOJFE/article/vi ew/610

Anggani, D. I. E. (2016). ... Pengelolaan Reklame Oleh Dinas Pendapatan Pengelolaan Keuangan Dan Aset Daerah (Dppkad) Kabupaten Tegal Dalam Meningkatkan Pendapatan Asli Daerah .... Journal of Politic and Government Studies. https://ejournal3.undip.ac.id/index.php/jpgs/article /view/13419

Ardiansyah, F. (2015). Analisis Kinerja DPKAD Dalam Pengelolaan Pajak Hotel Guna Meningkatkan Kontribusi Terhadap Pendapatan Asli Daerah Kota Semarang. Journal of Politic and Government Studies. https://ejournal3.undip.ac.id/index.php/jpgs/article /view/8307

Ariyanti, R., Setiawan, S., \& Cahyati, N. (2020). Analisis Efektivitas Dan Kontribusi Penerimaan Pajak Reklame Terhadap Pendapatan Asli Daerah Kabupaten Pekalongan. ... and Accounting Journal.

http://103.114.35.30/index.php/balance/article/vie w/4183

ASMAWATI, A., \& HESTI, H. (2021). EFEKTIVITAS PAJAK PENERANGAN JALAN DAN KOTRIBUSINYA TERHADAP PENDAPATAN ASLI DAERAH DI KABUPATEN BERAU. ... 
Aris Triyono, Albetris, Sumantri dan Etty Siswati, Efektivitas dan Kontribusi Pajak Perhotelan terhadap Pendapatan Asli Daerah Kabupaten Indragiri Hulu Tahun 2013-2019

Trusted, Inspiring, Authentic Journal .... http://jurnal.umberau.ac.id/index.php/accountia/art icle/view/554

Barus, J. F., \& Kariono, K. (2013). PENINGKATAN PAJAK DAERAH DI MASA OTONOMI DAERAH DI KOTA MEDAN PROVINSI SUMATERA UTARA. ... Publik: Public Administration Journal. http://ojs.uma.ac.id/index.php/adminpublik/article/ view/1347

Benita, N., Adechandra, D., \& ... (2019). Analisis Potensi dan Realisasi Penerimaan Pajak Hotel di Kabupaten Pemalang. ... Journal of Social Science

https://ejournal.undiksha.ac.id/index.php/IJSSB/ar ticle/view/17588

Biringkanae, A., \& Tammu, R. G. (2021). PENGARUH PAJAK HOTEL, PAJAK RESTORAN, PAJAK HIBURAN TERHADAP PENDAPATAN ASLI DAERAH KABUPATEN TANA TORAJA. ... Galigo| Public Administration Journal. http://ojs.unanda.ac.id/index.php/ilagaligo/article/ view/722

Blunch, N. (2012). Introduction to Structural Equation Modelling Using SPSS and AMOS. In Introduction to Structural Equation Modelling Using SPSS and AMOS. https://doi.org/10.4135/9781446249345

Bustomi, T. (2021). Implementasi Kebijakan Pajak Reklame pada Badan Pengelolaan Keuangan Daerah Kabupaten Bandung Barat. Journal of Public Administration and Government. https://jurnal.fisip.untad.ac.id/index.php/JPAG/arti cle/view/137

Dwihandoko, T. H. (2020). EFEKTIVITAS PENERIMAAN PAJAK BUMI DAN BANGUNAN TERHADAP PENINGKATAN PENDAPATAN ASLI DAERAH KABUPATEN LAMONGAN (Studi Kasus ... ... Dan Manajemen): The Journal of Business and .... http://ejurnal.unim.ac.id/index.php/bisman/article/ view/622

Hafandi, Y., \& Romandhon, R. (2020). ... Daerah, Hasil Pengelolaan Kekayaan Daerah yang Dipisahkan, Retribusi Daerah, dan Lain-Lain Pendapatan Daerah yang Sah Terhadap Pendapatan Asli Daerah .... Journal of Economic, Management .... https://ojs.unsiq.ac.id/index.php/jematech/article/v iew/1337

Hahumury, M. A. I. (2018). PENGARUH PENDAPATAN PAJAK KENDARAAN BERMOTOR TERHADAP PENDAPATAN ASLI DAERAH DI MERAUKE. Musamus Journal of Economics Development. http://www.ejournal.unmus.ac.id/index.php/feb/art icle/view/1228

Handryani, F., Abduh, M., Nasution, F. A., \& Tarigan,
P. (2014). Efektivitas terhadap Pengutipan Pajak Parkir dalam Hubungannya dengan Peningkatan Pendapatan Daerah di Kota Medan Menurut Perda Kota Medan No. 10 .... In USU Law Journal. media.neliti.com.

https://media.neliti.com/media/publications/14229 -ID-efektivitas-terhadap-pengutipan-pajak-parkirdalam-hubungannya-dengan-peningkata.pdf

Hasanah, M., \& Anitasari, M. (2019). ANALISIS BELANJA DAERAH KOTA BENGKULU TAHUN 2014-2017 (TINJAUAN EFISIENSI DAN EFEKTIVITAS). ... Journal of Economic Development.

https://ejournal.unib.ac.id/index.php/convergencejep/article/view/10905

Hasbullah, Y., Fatimah, S., \& ... (2021). Analisis Pengaruh Belanja Daerah Terhadap Pertumbuhan Product Domestic Regional Bruto (PDRB) Di Kabupaten Lombok Barat Tahun 2014-2018. Journal of Economics .... http://ekonobis.unram.ac.id/index.php/ekonobis/ar ticle/view/73

Hidayat, F. N., \& Pahlevi, D. R. (2016). Analisis Efektivitas dan Efisiensi Retribusi Daerah di Kabupaten Pekalongan Tahun 2010-2014. ... Development Analysis Journal. https://journal.unnes.ac.id/sju/index.php/edaj/articl e/view/22025

Hilman, Y. A., \& Kartika, T. (2020). Dinamika Kelembagaan Sektor Pariwisata di Kabupaten Ponorogo. Indonesian Journal of Tourism and Leisure.

https://journal.lasigo.org/index.php/IJTL/article/vi ew/82

Ho, R. (2006). Handbook of Univariate and Multivariate Data Analysis and Interpretation with SPSS.

Irfani, M. S., Probowulan, D., \& ... (2019). (Artikel) Efektivitas, Daya Pajak dan Kontribusi Pajak Kendaraan Bermotor Tahun 2013-2017 di UPT Pengelolaan Pendapatan Daerah Provinsi Jawa Timur ... ... Journal of Social .... http://repository.unmuhjember.ac.id/4357/

Isrok, A. (2009). Korelasi Antara Peraturan Daerah (Perda) Bermasalah dengan Tingkat Investasi Ke Daerah. Ius Quia Iustum Law Journal. https://www.neliti.com/publications/82820/korelas i-antara-peraturan-daerah-perda-bermasalahdengan-tingkat-investasi-ke-da

Jainuri, M. G. (2019). Kepatuhan Wajib Pajak Kendaraan Bermotor: Studi Kritis Empiris di Daerah Khusus Istimewa Jakarta. In ... Hukum Udayana (Udayana Master Law Journal). ojs.unud.ac.id.

https://ojs.unud.ac.id/index.php/jmhu/article/down load/44967/31656

Jamli, A., \& Rahayu, A. (1997). Analisis pajak pembangunan I perhotelan sebagai sumber 
Aris Triyono, Albetris, Sumantri dan Etty Siswati, Efektivitas dan Kontribusi Pajak Perhotelan terhadap Pendapatan Asli Daerah Kabupaten Indragiri Hulu Tahun 2013-2019

pendapatan asli daerah: Studi kasus kotamadya Yogyakarta. Economic Journal of Emerging Markets.

https://journal.uii.ac.id/JEP/article/view/6840

Jaya, F. B., \& Nopiana, P. R. (2019). PENGARUH EFISIENSI DAN EFEKTIVITAS PAJAK HOTEL TERHADAPPENDAPATAN ASLI DAERAH KOTA BATAM. ... JOURNAL: Jurnal Ilmiah Mahasiswa. http://ejournal.upbatam.ac.id/index.php/scientia_j ournal/article/view/2619

Karini, R., \& Agustiani, I. N. (2018). KONTRIBUSI PENERIMAAN PENDAPATAN SEKTOR PARIWISATA TERHADAP PENDAPATAN ASLI DAERAH (PAD) KOTA BANDUNG. Tourism Scientific Journal. http://jurnal.stiepar.ac.id/index.php/tsj/article/view 151

Koromath, J. P. (2019). Efektivitas Pemungutan Pajak Hotel Dan Restoran Di Kabupaten Manokwari Provinsi Papua Barat. JFRES: Journal of Fiscal and Regional Economy .... http://jfres.unipa.ac.id/index.php/jfres/article/view 129

Kurniawan, H. S., Hadiati, S., \& ... (2021). Analisis Efektivitas Dan Kontribusi Penerimaan Uang Kuliah Tunggal Terhadap Pendapatan Blu di Universitas Negeri Malang. ... | E-Journal. http://jurnal.warta-

pendidikan.com/ojs/index.php/WP/article/view/10 6

Lianawati, A. (2015). Efektivitas Dan Konstribusi Penerimaan Bea Perolehan Hak Atas Tanah Dan Bangunan. Economics Development Analysis Journal.

https://journal.unnes.ac.id/sju/index.php/edaj/articl e/view/14826

Maulida, M., Wiyono, M. W., \& ... (2019). Analisis Efektivitas Penerimaan Pajak Bumi dan Bangunan Perdesaan dan Perkotaan (PBB-P2) Serta Kontribusinya Terhadap PajakDaerah Di Kabupaten Lumajang .... ...: Journal of .... http://jkm.stiewidyagamalumajang.ac.id/index.php /jra/article/view/172

Memah, E. (2013). Efektivitas Dan Kontribusi Penerimaan Pajak Hotel Dan Restoran Terhadap Pad Kota Manado. Jurnal Riset Ekonomi, Manajemen, Bisnis Dan Akuntansi, 1(3), 871-881. https://doi.org/10.35794/emba.v1i3.1896

Nababan, D., \& Putra, I. G. S. (2018). Analysis contribution and effectiveness of local taxes toward original regional income at Bandung City. In International Journal of Engineering and .... researchgate.net.

https://www.researchgate.net/profile/Ivan_Putra5/ publication/329943961_Analysis_contribution_an d_effectiveness_of_local_taxes_toward_original_r
egional_income_at_Bandung_City/links/5fa3ac6d a6fdcc0624150c91/Analysis-contribution-andeffectiveness-of-local-taxes-toward-originalregional-income-at-Bandung-City.pdf

Nathania, W. (2019). ANALISIS EFEKTIVITAS PENERIMAAN PAJAK DAERAH SERTA KONTRIBUSINYA TERHADAP BELANJA DAERAH (Studi Kasus Pemerintah Provinsi DKI JAKARTA $\quad . . . \quad$ TECHNOBIZ: International Journal of Business. http://ejurnal.teknokrat.ac.id/index.php/technobiz/ article/view/274

Ningsih, S. (2017). ANALYSIS OF BILLBOARD CONTRIBUTION TAX TO REGIONAL INCOME OF SUKOHARJO DISTRICT IN YEAR 2012-2016. International Journal of Economics, Business and .... http://jurnal.stieaas.ac.id/index.php/IJEBAR/article/view/394

Pitriyani, A. I. (2020). ... Memengaruhi Potensi Penerimaan Pajak Parkir Di Kabupaten Bandung Barat (Studi Kasus Pada Badan Pengelolaan Keuangan Daerah Kabupaten Bandung Barat). Indonesian Accounting Research Journal. https://jurnal.polban.ac.id/ojs-

3.1.2/iarj/article/view/2362

Pramesthi, P. D., \& Adnan, M. (2015). Evaluasi Efektivitas Penerimaan Pajak Kendaraan Bermotor sebagai Sumber Pendapatan Asli Daerah Tahun 2010-2014 Provinsi Jawa Tengah. Journal of Politic and Government .... https://ejournal3.undip.ac.id/index.php/jpgs/article /view/8881

Pratiwi, I., Amiludin, A., \& Asmawi, M. (2021). KEBIJAKAN DINAS PENANAMAN MODAL DAN PELAYANAN TERPADU SATU PINTU (DPMPTSP) DALAM PEMBERIAN PERIZINAN SELAMA PANDEMI COVID-19. Indonesian Journal of Law and .... http://jurnal.umt.ac.id/index.php/IJLP/article/view 14297

PRESIDENRI. (2004). PERIMBANGAN KEUANGAN ANTARA PEMERINTAH PUSAT DAN PEMERINTAHAN DAERAH. 33, 2004-2006. https://luk.staff.ugm.ac.id/atur/UU33-

2004PerimbanganKeuanganLengkap.pdf

Purnamawati, I. G. A. (2014). Pelaksanaan Peraturan Daerah Nomor 7 Tahun 2011 Dalam Menunjang Pendapatan Asli Daerah dari Sektor Retribusi Parkir Kendaraan Roda Dua. Pandecta Research Law Journal. https://journal.unnes.ac.id/nju/index.php/pandecta/ article/view/3002

Puspitasari, E. R. A., \& Rohman, A. (2014). Analisis Efektivitas, Efisiensi, Dan Kontribusi Pajak Daerah Dan Retribusi Daerah Terhadap Peningkatan Pad Kabupaten Blora Tahun 20092013. Diponegoro Journal of .... 
Aris Triyono, Albetris, Sumantri dan Etty Siswati, Efektivitas dan Kontribusi Pajak Perhotelan terhadap Pendapatan Asli Daerah Kabupaten Indragiri Hulu Tahun 2013-2019

https://ejournal3.undip.ac.id/index.php/accounting /article/view/10198

Raysa, R., \& Purba, N. M. B. (2020). EVALUASI TERHADAP KINERJA PEMUNGUTAN PAJAK BUMI DAN BANGUNAN DAN KONTRIBUSINYA TERHADAP PENDAPATAN DAERAH DI KOTA BATAM. SCIENTIA JOURNAL: Jurnal ... http://ejournal.upbatam.ac.id/index.php/scientia_j ournal/article/view/2253

Renindita, A., \& Novianty, I. (2020). Pengaruh Kontribusi Pajak Restoran Terhadap Pendapatan Asli Daerah Di Kota Bandung. ... Research Journal. https://jurnalakuntansi.polban.ac.id/iarj/article/view/23

Rohma, F. (2017). Kontribusi Pajak Hotel dan Restoran Dalam Meningkatkan Pendapatan Asli Daerah Kota Sidoarjo. E-Journal Akuntansi" EQUITY". http://fe.ubhara.ac.id/ojs/index.php/equity/article/v iew/519

ROHMAN, M. (2016). Pelayanan Pajak Reklame di Kabupaten Jember. repository.unmuhjember.ac.id. http://repository.unmuhjember.ac.id/866/

Ruslan, D. (2016). Analisis Kinerja Perpajakan Daerah Di Kota Medan. Quantitative Economics Journal. https://jurnal.unimed.ac.id/2012/index.php/qe/artic le/view/17491

Sahrudin, S. (2017). Upaya Peningkatan Pajak Daerah dalam Mendukung Pelaksanaan Otonomi Daerah di Kabupaten Bima. JABE (Journal of Applied Business and http://journal.lppmunindra.ac.id/index.php/JABE/ article/view/1778

Said, A., \& Ode, L. (n.d.). Strategi Mengatasi Ketergantungan Pemerintah Daerah Kabupaten Konawe Utara terhadap Dana Perimbangan Pusat. Journal Publicuho. https://www.neliti.com/publications/279521/strate gi-mengatasi-ketergantungan-pemerintah-daerahkabupaten-konawe-utara-terha

Samosir, M. S. (2020). Analisis Pengaruh Kontribusi dan Efektivitas Pajak Hotel, Restoran dan Hiburan Terhadap Pendapatan Asli Daerah Pada Badan Pendapatan Daerah .... In Journal of Public Administration and .... jurnal.fisip.untad.ac.id. https://jurnal.fisip.untad.ac.id/index.php/JPAG/arti cle/view/38

Saputra, A., \& Nurfitriana, N. (2020). A Realization Analysis Of Received Motor Vehicle Tax And Behavior Of Motor Vehicle Name In The Regional Income Agency Of Central Sulawesi Province. Economy Deposit Journal (E-DJ). https://uit.e-journal.id/EDJ/article/view/729

Soleh, A. (2020). ANALISIS PAJAK REKLAME DALAM UPAYA MENINGKATKAN PAD DI KABUPATEN SAROLANGUN. Journal
Development.

http://jurnal.umjambi.ac.id/index.php/JD/article/vi ew/146

Suhono, S., \& Sulastri, E. M. (2017). Analisis Kontribusi dan Efektivitas Pajak Daerah Sebagai Sumber Pendapatan Aali Daerah Kabupaten Karawang. ...: Journal of Accounting and Finance.

https://journal.unsika.ac.id/index.php/accounthink/ article/view/729

Sunanto, S. (2017). ANALISIS EFISIENSI DAN EFEKTIVITAS PENERIMAAN PENDAPATAN ASLI DAERAH TERHADAP ANGGARAN PENDAPATAN DAN BELANJA DAERAH (APBD) DI .... ... : Journal Research Accounting Politeknik

http://ejournal.poltektegal.ac.id/index.php/monex/ article/view/452

Susanto, J., \& Anggraini, Z. (2019). KINERJA DINAS PERHUBUNGAN KABUPATEN BUNGO DALAM MENINGKATKAN PENDAPATAN ASLI DAERAH MELALUI RETRIBUSI PENGUJIAN KENDARAAN .... Public Administration Journal of .... http://paj.upnjatim.ac.id/index.php/paj/article/view 136

Susianti, E. E., Wisnaeni, F., \& ... (2016). Pelaksanaan Tugas dan Wewenang Dinas Pengelolaan Keuangan dan Aset Daerah Kabupaten Blora dalam Rangka Pelaksanaan Otonomi Daerah. Diponegoro Law Journal. https://ejournal3.undip.ac.id/index.php/dlr/article/ view/12889

Thakkar, J. J. (2013). Structural Equation Modelling. https://doi.org/10.1108/s14793512(2013)0000027012

Triwinarso, A. (2018). POTENSI, EFEKTIVITAS DAN KONTRIBUSI PAJAK HOTEL DI KABUPATEN SLEMAN PERIODE 2012-2016. SOLUSI http://repository.poltekapi.ac.id/id/eprint/52

Wahyuni, R. A. P., \& Arief, K. (2020). Pengaruh Efektivitas dan Kontribusi Penerimaan Pajak Daerah Terhadap Pendapatan Asli Daerah Kabupaten Bandung. ... Accounting Research Journal. https://jurnal.polban.ac.id/ojs3.1.2/iarj/article/view/2365

Yasa, I. N. G. (2020). ... ) DAN PAJAK BUMI DAN BANGUNAN SEKTOR PERDESAAN DAN PERKOTAAN (PBB P2) SERTA KONTRIBUSINYA TERHADAP PENDAPATAN ASLI DAERAH .... SIMPLEX: Journal of Economic Management. http://scholar.ummetro.ac.id/index.php/simplex/art icle/view/346

Zainita, E., Sari, Y. P., \& Mulyadi, M. (2016). ANALISIS EFEKTIVITAS RETRIBUSI SEWA 
Aris Triyono, Albetris, Sumantri dan Etty Siswati, Efektivitas dan Kontribusi Pajak Perhotelan terhadap Pendapatan Asli Daerah Kabupaten Indragiri Hulu Tahun 2013-2019

ALAT LABORATORIUM UJIMATERIAL

PADA DINAS PERINDUSTRIAN DAN

PERDAGANGAN KABUPATEN .... In Monex:

Journal of .... ejournal.poltektegal.ac.id. http://ejournal.poltektegal.ac.id/index.php/monex/ article/viewFile/325/319 